The Astra Group : a pi oneer of management moder ni zat i on in I ndonesi a

\begin{tabular}{|c|c|}
\hline 権利 & $\begin{array}{l}\text { Copyr i ght s 日本貿易振興機構 (ジェトロ } \text { アジア } \\
\text { 経济研究所 / I nst i t ut e of Devel opi ng } \\
\text { Economi es, Japan Ext er nal Tr ade Organi zat i on } \\
\text { ( I DE- JETRO) ht t p: // www. i de. go.j p }\end{array}$ \\
\hline $\begin{array}{l}\text { j our nal or } \\
\text { publ i cat } i \text { on } t i t l e\end{array}$ & The Devel opi ng Econom es \\
\hline vol une & 34 \\
\hline nunber & 3 \\
\hline page $r$ ange & $247-280$ \\
\hline year & 1996- 09 \\
\hline 出版者 & I nst i tute of Devel opi ng Economi es \\
\hline URL & ht t p: //doi . or g/10. 20561/00028786 \\
\hline
\end{tabular}


The Developing Economies, XXXIV-3 (September 1996)

\title{
THE ASTRA GROUP: A PIONEER OF MANAGEMENT MODERNIZATION IN INDONESIA
}

\author{
YURI SATO
}

\section{INTRODUCTION}

$\mathrm{T}$

HE purpose of this paper is to describe the management system built by the Astra Group in conjunction with its development of the machinery industry and to attempt to identify why the Astra Group was able to become the pioneer of management modernization in Indonesia.

The Astra Group is one of Indonesia's leading business groups. The group's holding company, PT Astra International Incorporated, which had 125 affiliated companies under its corporate umbrella in 1995, boasts the largest net sales of the 238 companies listed on the Indonesian stock exchange market.

The Astra Group has three main features. First it holds over 50 per cent of the market share making it the largest automaker in Indonesia, Taking advantage of joint ventures using Japanese automobile capital, Astra laid down its business foundations in the manufacturing of automobiles and machinery.

Its second feature is that it was a family business founded by William Soeryadjaya (Chinese name: Tjia Kian Liong; referred to below as "William"), who was born in 1923 in Majalenka in West Java. The holding company, PT Astra International, had long been held exclusively by William and his children until the end of 1992, when the fragility of family business became apparent. It was then that the founding family disposed of its shareholdings of PT Astra International because of the bankruptcy of a separate family business. As a result, PT Astra International and its affiliated companies, apart from the founding family's ownership, came to be held by multiple owners, including Indonesian government financial institutions, domestic private capitalists, and foreign firms. ${ }^{1}$

The author would herein like to express her deep appreciation to the many individuals in Indonesia and Japan who cooperated in regard to this study, including PT Astra International's directors, personnel from AI's public relations and financial divisions, representatives of Toyota-Astra Motor, Toyota Motor Company, and Komatsu.

${ }^{1}$ Up to the end of 1992, the term "Astra Group" refers to the entire group of companies owned by the founding family. This covers about ten holding companies, including PT Astra International, and their respective subsidiaries. At the end of 1992, PT Astra International and its direct and indirect affiliated companies separated from the above group of companies and became the present Astra Group (or the Astra International Group). 
Fig. 1. PT Astra International's Seven Divisions

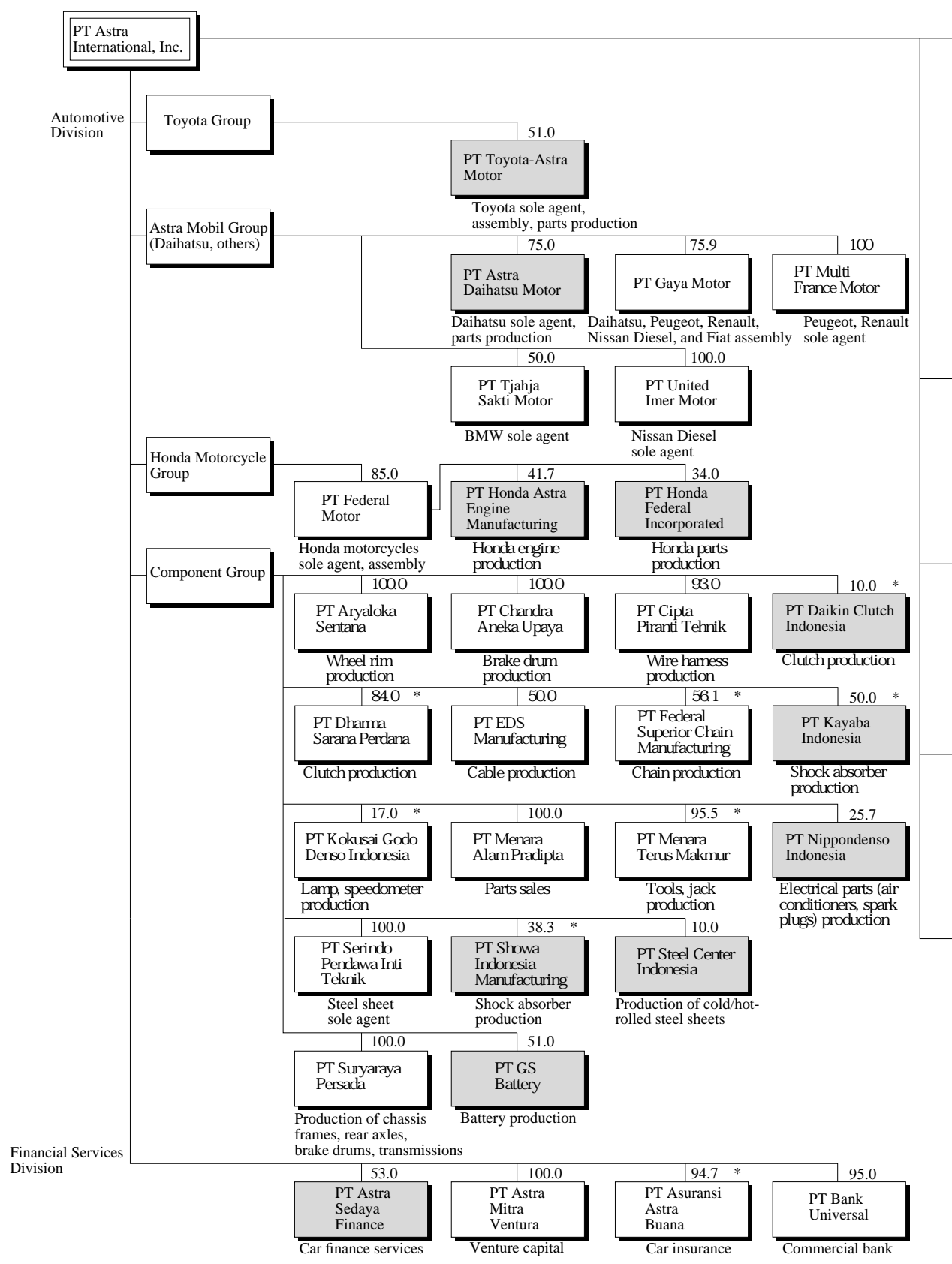

Source: Based on [7] [4, 1995 edition].

Note: Percentages of ownership with mark * include the AI's indirect investment through other affili- 
and the Main Affiliated Companies, 1995

Heavy Equipment

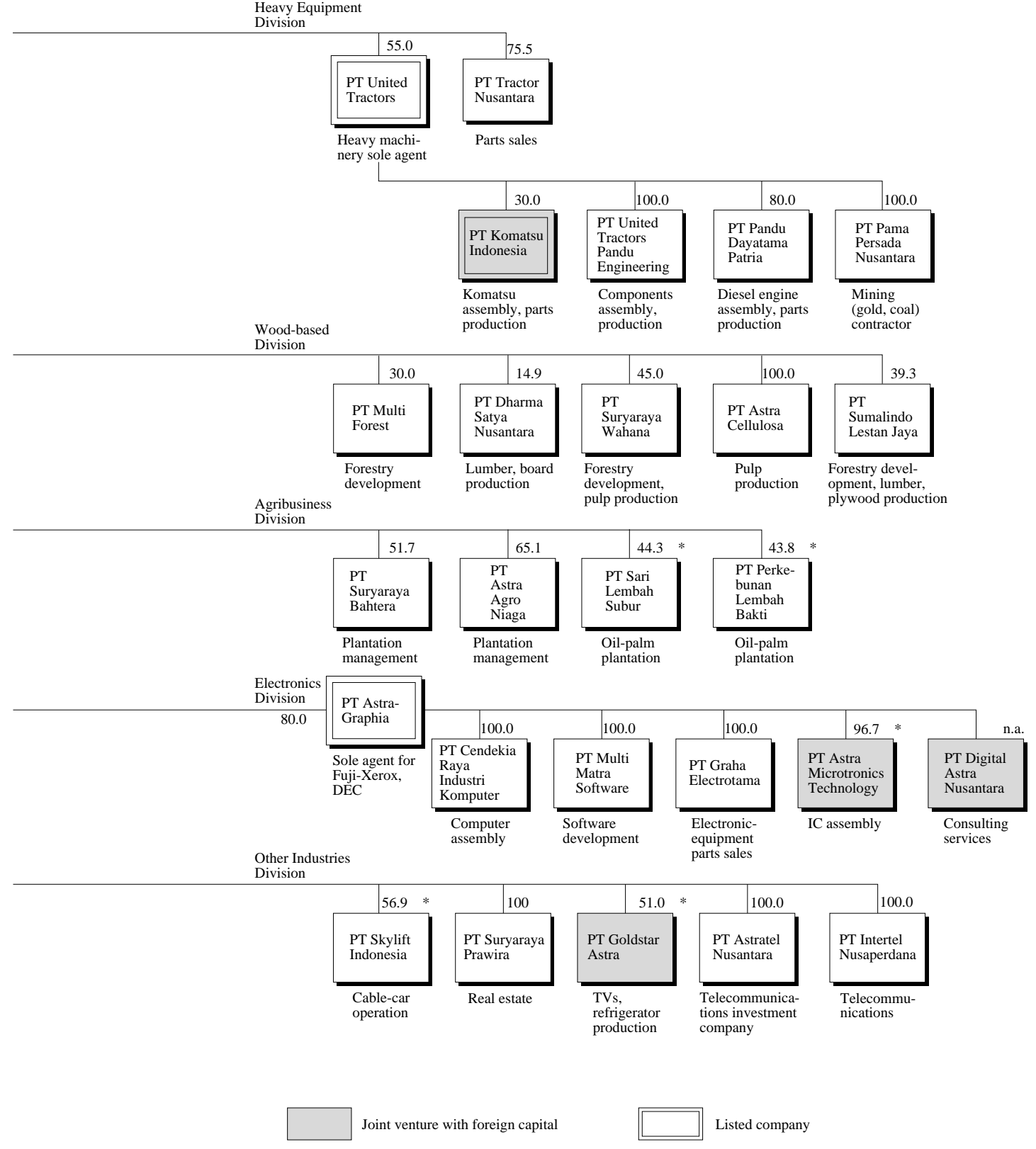

ated companies. 
The third feature of the Astra Group is as the pioneer of management modernization. The Astra Group introduced the divisional system and the holding company system in the 1970s and "total quality control" (TQC) at the onset of the 1980s. Astra, which was the first Indonesian private company to issue bonds on the overseas and domestic financial markets, was also the first Indonesian business group to have its holding company listed on the domestic stock market. Astra won high esteem abroad for its modern management, and this esteem did not diminish in the wake of the bankruptcy suffered by the founding family. ${ }^{2}$

It is noteworthy that the modernization of the management of the Astra Group steadily progressed from the initial stages of the group's growth, despite the exclusive ownership by the founding family. The existence of this management system, which had been carefully built up over time, enabled the Astra Group to survive the collapse of the family ownership and for it to continue to grow. The process of management modernization appears to be closely related to the formation of the group's business foundations in the automotive and machinery industries with the introduction of Japanese capital and technology.

Section I of this paper will examine the process of development of the Astra Group's businesses in the automotive and machinery industries. Section II will analyze the group's management system from the perspectives of organization, finance, and managers, and examine its current status after the separation from the founding family's ownership. Through the above analyses, the author will consider why the Astra Group was able to build a modernized management system in conclusion.

\section{THE DEVELOPMENT OF THE AUTOMOTIVE AND MACHINERY INDUSTRIES AS THE GROUP'S BUSINESS FOUNDATIONS}

\section{A. Overview of the Astra Group's Businesses}

The Astra Group had a total of 105,000 employees, net sales of Rp 12.6 trillion (approximately U.S.\$5.6 billion) and total assets of Rp 15.6 trillion (U.S. \$6.9 billion) in 1995 [4, 1996 ed.]. In terms of sales, the group contests second place in the Indonesian business-group ranking with the Sinar Mas Group, following only the leader, the Salim Group.

PT Astra International (referred to as AI below) has seven divisions, under which a total of 125 companies with AI's direct and indirect shareholdings are placed (Figure 1). The seven divisions are:

1. automotive, including cars, motorcycles, and components;

\footnotetext{
2 For example, PT Astra International was selected as the best Indonesian company on the basis of comprehensive criteria ("Review 200: Asia's Leading Companies," Far Eastern Economic Review, December 28, 1995-January 4, 1996, pp. 72-73).
} 
2. financial services, mainly automobile financing;

3. heavy equipment;

4. wood-based;

5. agribusiness;

6. electronics, including office equipment and semiconductors; and

7. other businesses, including sheet glass, monosodium glutamate, and TVs and refrigerators.

The automotive division accounts for about 50 per cent of the group in terms of number of direct subsidiary companies and $70-80$ per cent in terms of profits. The three machinery-related divisions, adding heavy equipment and electronics, account for as much as 90 per cent of the total group profits.

Table I presents indices that show the expansion process of the Astra Group. An examination of these figures reveals that the number of group companies of the Astra Group, which was only four in 1969 in the early years of the Suharto government, had increased to more than 100 by the beginning of the 1980s. The total capital of the group companies had grown at an average annual rate of 56.8 per cent from 1970 to 1980 and had expanded by approximately ninety times. During that

TABLE I

The Expansion of the Astra Group, 1957-95

\begin{tabular}{|c|c|c|c|c|c|c|c|}
\hline & \multicolumn{2}{|c|}{ Astra Group } & \multicolumn{5}{|c|}{ PT Astra International's Direct/Indirect Affiliated Companies } \\
\hline & $\begin{array}{c}\text { No. of } \\
\text { Companies }\end{array}$ & $\begin{array}{l}\text { Total Issued } \\
\text { Capital } \\
\text { (Rp Million) }\end{array}$ & $\begin{array}{c}\text { No. of } \\
\text { Companies }\end{array}$ & $\begin{array}{l}\text { Total Issued } \\
\text { Capital } \\
\text { (Rp Million) }\end{array}$ & $\begin{array}{c}\text { Assets } \\
\text { (Rp Billion) }\end{array}$ & $\begin{array}{c}\text { Sales }^{\mathrm{a}} \\
\text { (Rp Billion) }\end{array}$ & $\begin{array}{c}\text { No. of } \\
\text { Employees } \\
(1,000)\end{array}$ \\
\hline 1957 & 1 & 0.5 & 1 & 0.5 & - & - & $\ldots$ \\
\hline 1965 & 2 & 8 & 1 & 0.5 & - & - & $\ldots$ \\
\hline 1969 & 4 & 613 & 2 & 505 & - & - & $\ldots$ \\
\hline 1974 & 35 & 14,900 & 12 & 8,036 & (42.3) & (72.1) & $\ldots$ \\
\hline 1980 & 82 & 54,902 & 29 & 37,796 & 245.6 & 487.6 & $\ldots$ \\
\hline 1982 & 101 & 133,352 & 34 & 80,841 & $\begin{array}{c}429.4 \\
(164.0)\end{array}$ & $\begin{array}{c}662.4 \\
(292.0)\end{array}$ & $\ldots$ \\
\hline 1985 & 121 & 221,792 & 38 & 132,042 & & 768.5 & 20.3 \\
\hline 1988 & $\ldots$ & $\ldots$ & $\ldots$ & $\ldots$ & $(609.0)$ & $2,201.5$ & 28.0 \\
\hline 1990 & $\ldots$ & $\ldots$ & 72 & $\ldots$ & $3,248.1$ & $4,309.3$ & 39.5 \\
\hline 1992 & $\ldots$ & $\ldots$ & 69 & $\ldots$ & $5,115.0$ & $4,462.7$ & 75.5 \\
\hline 1994 & $73^{b}$ & $\ldots$ & $73^{b}$ & $\ldots$ & $10,180.8$ & $9,506.9$ & 83.0 \\
\hline 1995 & 125 & $\ldots$ & 125 & $\ldots$ & $15,617.0$ & $12,620.0$ & 105.0 \\
\hline
\end{tabular}

Sources: Calculated from the articles of incorporation for each company contained in [3], [6] and [4] (1974, 1980, 1982, 1989, 1992, 1994, 1995 editions), [7], and informational materials from Astra International's PR division.

Note: - indicates that no figures are applicable, and ... indicates that the figure is not available.

a On consolidated basis; within parentheses = AI nonconsolidated.

b Excluding the four companies that were in the disposal process. 
period, the companies established as AI's affiliated companies accounted for more than 60 per cent of the group in terms of capital, and most of those AI-invested companies were related to the automotive and machinery industries. By the beginning of the 1980s, the framework of the Astra Group, based on the machinery industry-related companies under AI's shareholding, had taken shape. Companies in non-machinery industries such as forestry, automobile financing services, and miscellaneous export goods were initially established outside the AI's purview and were gradually brought under the AI's shareholding from the latter half of the 1980s.

In this way the business of the Astra Group developed and centered on machinery-related industries. The Astra Group stands on this point in stark contrast to conglomerates such as the Salim Group, which straddles a broad range of unrelated industries, ranging from foods to cement, automobiles, and chemicals.

We now will examine the development of the Astra Group's machinery industry.

\section{B. The Beginning of Its Automobile Business}

The Astra Group's first encounter with the automobile business dates back to 1967, at the beginning of economic activities under the Suharto government.

AI, the mother company of the Astra Group, which was established in Jakarta in 1957, was initially involved in sales of juice and daily goods as well as exports of primary products. In the 1960s, the company became a contractor for public works projects [5, 1982, pp. 11-12]. In 1967, AI acquired an import license (Bonus Ekspor Kredit) under the U.S. government's commodity aid program, subcontracting for the import of GM (General Motors)-made generators that had been ordered by the Indonesian state-owned electric power corporation PLN (Perusahaan Listik Negara). However, the U.S. government insisted that importers submit public bids when the source of the order was a government, which resulted in a halt to AI's loading of the generators. AI, which had been left in a predicament, then imported 800 Chevrolet trucks from GM as a substitute for the suspended order and quickly succeeded in selling the lot to the Indonesian government [8, pp. 13-14].

In the wake of this success, AI was asked by Suhartojo, the then Director General for the Metal and Machinery Industry of the Ministry of Industry, to handle the reconstruction of PN Gaya Motor, the state-owned assembly company that was at that time the agent for Chevrolet. PN Gaya Motor is a plant that was originally established in 1927, in the then Batavia, as GM's first direct investment in Southeast Asia. After GM's withdrawal from Indonesia in 1954, the plant became stateowned; however, assembly production declined toward the end of the Sukarno era due to the obsolescence of the plant's equipment and a lack of foreign currency. In 1969, AI invested over U.S.\$1 million [1, p. 106] to take a 60 per cent shareholding and PN Gaya Motor invested in kind (land and equipment) to take a 40 per cent 
shareholding, which resulted in the establishment of a semi-governmental, semiprivate PT Gaya Motor, with Astra taking charge of management [3, 1970-54]. However, the sole agency to represent Chevrolet, which Astra expected to retain, was transferred to another firm, and the sole agency for the Nissan Motor Co. Ltd., was also declined, though it had been in contact [8, p. 14].

At this point, the reconstruction of Gaya Motor is linked with the Toyota Motor Co. Ltd. Toyota, which had opened a representative office in Jakarta in 1968 as its second base in Asia following Thailand, awarded sole agency to AI in 1969. The awarding of these rights was undeniably facilitated by the facts that AI was in a business partnership with the government and that the then Minister of Trade in charge of supervising sole agency allocation was Sumitro Djojohadikusumo, with whom William had since the mid-1950s maintained a "personal relationship." ${ }^{3}$ PT Toyota-Astra Motor, a company held jointly by Toyota and Astra, was set up in 1971 as the sole agent handling imports and sales of Toyota vehicles. The shareholding structure of PT Toyota-Astra Motor was composed of a 36.2 per cent held by AI, a 14.8 per cent held by PT Gaya Motor and a 49 per cent held by Toyota [3, 1971-601]. This resulted from an agreement among the participants designed so that majority ownership would be in Indonesian hands while management was exerted by Toyota. ${ }^{4}$ The reasons why Indonesia insisted on majority ownership are thought to be because the business had a governmental nature due to the indirect government investment and because the business was of a distribution industry in which the government wanted to exclude foreign capital. In fact, the government banned the presence of foreign-invested firms in the sole agent business the following year (1972), and only Toyota and Mercedes-Benz were allowed to remain as sole agents with a joint venture configuration because they had been established prior to the ban.

In this way, AI went from being a completely unknown company to becoming a partner of the government and a partner of Toyota within two years from 1969. The first point to note in regard to this process is the support AI received from the government. This support consisted of AI's acquisition of an import license from the government and its subsequent joint venture with the Ministry of Industry, as well as AI's opportunity for a joint venture with Toyota which resulted from backing from both the Ministry of Industry and the Ministry of Trade. The second point is that the joint venture with Toyota decided the direction of Astra's business

\footnotetext{
3 When Sumitro succeeded William, who was confronting the financial crisis in a family business, in 1992 as the chairman of AI's board of commissioners, he stated "William and I have had a personal relationship since 1955" ("Mengapa si Oom Mengundang Pak Mitro" [Why did William invite Mr. Sumitro?], Editor [Jakarta], August 8, 1992, p. 33). That (1955) was the period when Sumitro was Minister of Finance under the Sukarno government. It is said that Sumitro and William maintained their personal relationship during the 1958-67 period, when Sumitro took refuge overseas.

${ }^{4}$ Based on interviews conducted by the author with persons affiliated with Astra and Toyota.
} 
course thereafter; to participate in a localization program in machinery manufacturing with a focus on the automobile industry, and also to develop strong ties with Japanese capital and technology.

\section{The Development of the Machinery Business}

The development of the Astra Group's machinery business can be divided into four stages: (1) the acquisition of multiple sole agencies beginning with Toyota, (2) the commencement of assembly and component production, (3) horizontal and vertical integration, and (4) the beginning of exports of components and products (Table II). Stages (1) and (2), which were supported by the expansion of the domestic car market during the oil boom, took place during the period when the Astra Group was taking shape as a business group. Stage (3) took place during the period after the oil boom when the car market diminished. Stage (4) corresponds to the period of the growing export orientation of the Indonesian macroeconomy.

Stage (1) was marked by the concentrated acquisition of sole agencies in cars, heavy machinery, and office equipment. During 1969-73, AI acquired sole agencies for Toyota, Peugeot, Daihatsu (cars), Honda (motorcycles), Fuji-Xerox (copy machines), and Komatsu (heavy machinery [marked by star is in Table II]). The reasons why it was able to acquire so many sole agencies within such a short period was thought to be due to Astra's connection with the Minister of Trade and the reputation it had won as a partner of the government and a partner of Toyota. But what the author would like to emphasize is the fact that Astra's own courageous behavior and decision-making were behind the acquisition of these sole agencies, as the following event will show. Astra had been the sole agent for the U.S. manufacturer of heavy machinery Allis-Chalmers from the end of the 1960s. When Astra came in contact with Komatsu in 1972, Komatsu asked Astra to choose either Allis-Chalmers or Komatsu. Astra immediately decided to switch to Komatsu. The speed of the decision surprised even Komatsu itself because at that time U.S. manufacturers held the top three places in the world market for heavy machinery (Allis-Chalmers was ranked second), while Komatsu held only the sixth or seventh ranking. ${ }^{5}$ This event indicates that Astra's acquisition of sole agencies from multiple Japanese manufacturers was based on clear business judgments by the Astra management, which had decided to go with Japan.

Stage (2) marks the commencement of car assembly and component production. The establishment of assemblers in the first half of the 1970s was followed by the establishment of component manufactures in the second half of the decade (indicated by the shift of the $\bigcirc$ symbol from columns 1 to 5 in Table II.) Because each of the assembly and component firms were established as a separate firm (the $\bigcirc$ symbol indicates one firm) and most were established as direct or indirect affiliated

\footnotetext{
5 Based on interviews conducted by the author with Mr. S. Nakamura, who was Komatsu's first
} representative stationed in Jakarta. 
TABLE II

The Development of the Astra Group’s Machinery Business, 1989-93

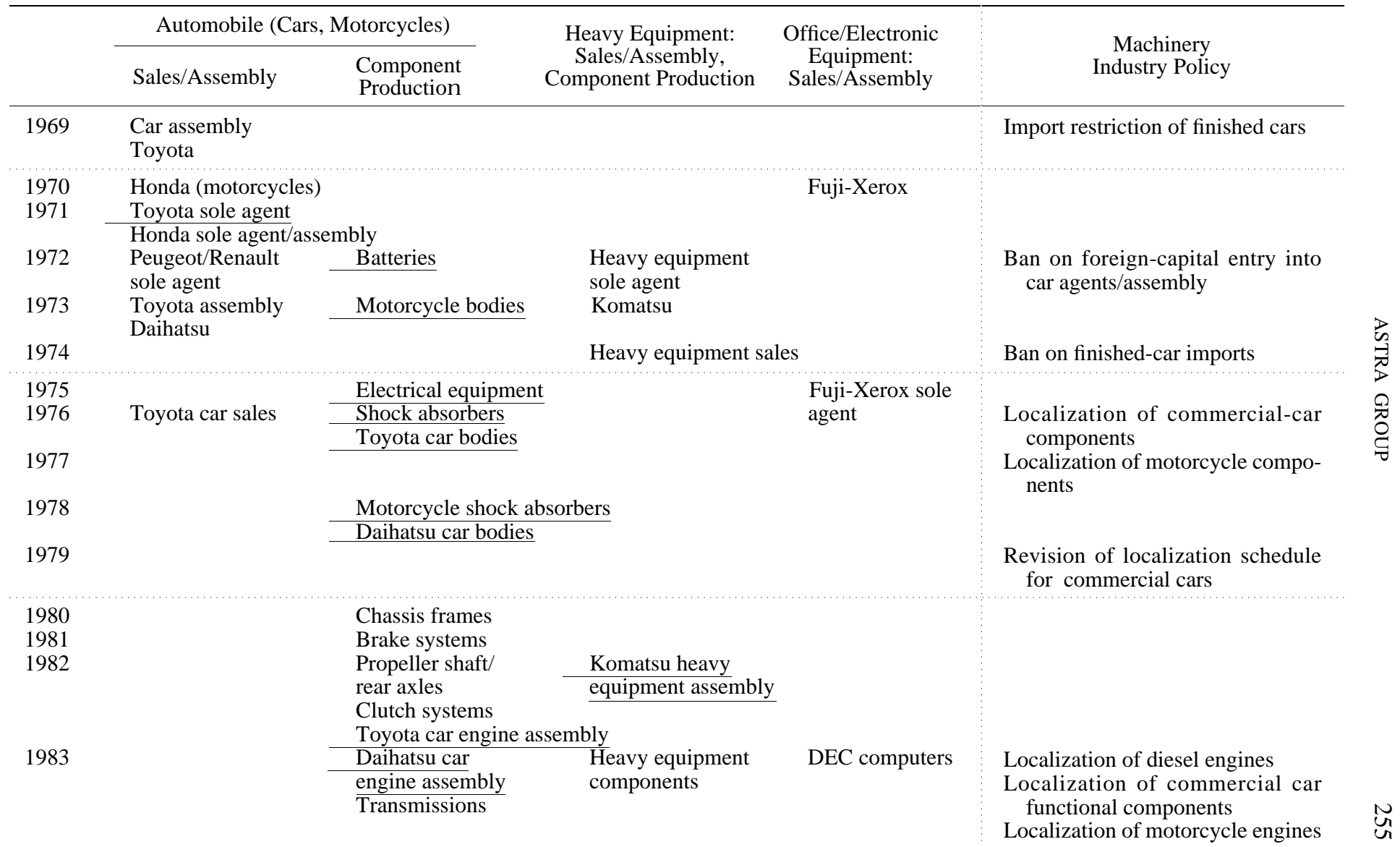


TABLE II (Continued)

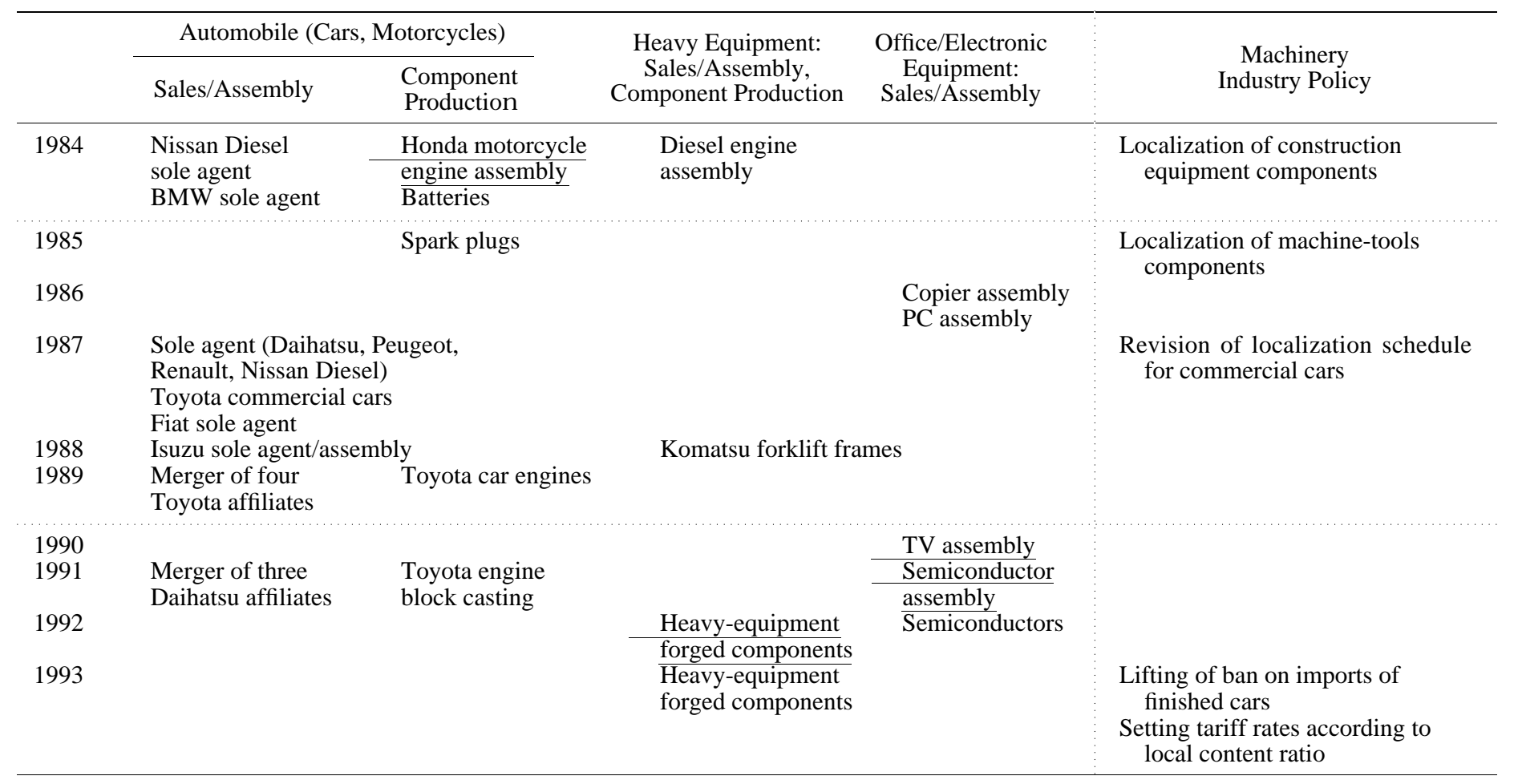

Sources: Based on Edisi khusus: 25 tahun Astra, 1957-1982 [Special issue: Twenty-five years of Astra, 1957-82] (Jakarta, 1982); [5, various issues]; the articles of incorporation for each company contained in [3]; and other materials.

Notes: 1. "Localization" in the policy column refers to the mandatory use of domestic products for the specified component.

2. 访: Acquisition of sole agencies. $\bigcirc$ : Establishment of new company.

: Acquisition of company. $\quad \nabla:$ Merger or new business of existing group companies.

3. Underlined are joint ventures with foreign capital. 
companies of AI, they formed a business group with $\mathrm{AI}$ at its core at the beginning of the 1980s. The components that were produced in the 1970s were body parts for Honda motorcycles, Toyota and Daihatsu commercial vehicles, and general components such as batteries, electrical equipments, and shock absorbers. It should be noted that all of the seven component firms shown on the table are joint ventures with Japanese firms. The Astra Group's launch of component production was, rather than aiming at economic effects like cost cuts, prompted entirely as the group's response to the government's component localizing program for commercial vehicles, which was announced in 1976 (see the column 5 in Table II). As proof of this, though Astra's acquisition of sole agencies for heavy machinery took place as early as those for cars, Astra's production of components for heavy machinery was delayed because the start of the government localization policy was delayed until 1983. In addition, electronic equipment, which was never subjected to a consistent localization policy, had only progressed to the assembly stage by the latter part of the 1980s. This fact reflects the Astra Group's scrupulous adherence to the government's localization policies in its development of the machinery sector of its business.

Stage (3) is the horizontal and vertical integration of the automobile industry carried out by the Astra Group in the 1980s, when the car market was diminishing. The Astra Group achieved a total car market share of 40 per cent (including Toyota, Daihatsu, Peugeot, and Renault) in 1977 (Table III), giving it the leading role in the industry. In the latter half of the 1980s, it made acquisitions of the sole agencies of Nissan Diesel, BMW, Fiat, and Isuzu from the former agency-holders (indicated by the black circle in Table II), and realigned these eight brands within the group. The Astra Group's market share rose above 50 per cent in 1990 due to this horizontal integration.

Meanwhile, the Astra Group established eight firms producing functional components for commercial vehicles such as chassis frames, brakes, and engines in 1980-84, thereby extending the range of the group's vertical integration from body and general components to core components. In the same period, the group moved from assembly, to the production of engines in the heavy machinery area. Figure 2 shows a comparison of the Astra Group with other automakers in terms of whether or not six functional components are procured within the group or outsourced (firms within the box are in-group firms). It is clear from the figure that the Astra Group is the only automaker that procures all six items within the group. In regards to these functional components, the government used a licensing system to limit the issuance of licenses to between one and three firms for each item in order to ensure a minimum production scale. In this situation, the Astra Group secured licenses for all items because Astra, which is a model proponent of the government's policies, was in a favorable position to secure the limited licenses. The acquisition of brands mentioned previously was enabled by Astra's deep resources of capital, 
Fig. 2. In-Group Procurement of Functional Components for Commercial Vehicles by the Astra Group, 1991

\begin{tabular}{|c|c|c|c|c|c|c|c|c|c|c|}
\hline \multirow{2}{*}{$\begin{array}{l}\text { Local business group } \\
\text { Foreign automaker }\end{array}$} & \multicolumn{4}{|c|}{ Astra } & \multicolumn{3}{|c|}{ Indomobil } & \multirow{2}{*}{$\begin{array}{c}\text { Krama Yudha } \\
\text { Mitsubishi }\end{array}$} & \multirow{2}{*}{$\begin{array}{l}\text { Imora } \\
\text { Honda }\end{array}$} & \multirow{2}{*}{$\begin{array}{c}\text { Bimantara } \\
\text { Mercedes- } \\
\text { Benz }\end{array}$} \\
\hline & Toyota & Daihatsu & $\begin{array}{l}\text { Nissan } \\
\text { Diesel }\end{array}$ & Isuzu & Suzuki & Mazda & Hino & & & \\
\hline Engine & TAM & $\mathrm{ADM}$ & PDP & MII & ISI & MIM & HIM & MKY & HPE & SEI \\
\hline Rear body & TAM & $\mathrm{ADM}$ & - & - & ISI & MIM & HIM & MKY & $\mathrm{IH}$ & - \\
\hline Shassis frame & GKD & GKD & GKD & - & n.a. & - & GKD & GKD & - & - \\
\hline $\begin{array}{l}\text { Propeller shaft, } \\
\text { Rear axle }\end{array}$ & IGP & IGP & IGP & IGP & IGP & IGP & IGP & IGP & - & IGP \\
\hline Brake system & TDW & TDW & TDW & TDW & $\mathrm{TDW} \rightarrow \mathrm{CHN}$ & TDW & TDW & TDW & $\mathrm{CHN}$ & n.a. \\
\hline & & DSP & & & & & & & & \\
\hline Clutch system & DSP & & - & - & DCI & DCI & n.a. & DSP, DCI & - & DCI \\
\hline Transmission & WEP & WEP & WEP & WEP & $\mathrm{WEP} \rightarrow \mathrm{IWG}$ & IWG & WEP & WEP & - & - \\
\hline
\end{tabular}


Source: Based on interviews by the author with the Astra Group functional component companies and with Japanese automakers.

Group company within corresponding local business group.

Joint venture with corresponding foreign automaker.

Technological tie-up company with corresponding foreign automaker.

Absence of enclosure indicates that procurement is from companies outside the group, with which it has no capital or technologi-

cal ties.

$\rightarrow \quad$ Indicates change in procurement partner.

$\rightarrow \quad$ Indicates the applicable parts are imported.

n.a. Indicates that information is not available.

Companies producing engines/bodies:

TAM: PT Toyota-Astra Motor,

ADM: PT Astra Daihatsu Motor,

PDP. PT Pandu Dayatama Patria,

MII: PT Mesin Isuzu Indonesia,

ISI: $\quad$ PT Indomobil Suzuki International,

MIM: PT Mazda Indonesia Manufacturing,

HIM: PT Hino Indonesia Manufacturing,

MKY: PT Mitsubishi Krama Yudha Motors and Manufacturing,

HPE: PT Honda Prospect Engine Manufacturing,

IH: PT Imora Honda Incorporation,

SEI: PT Star Engine Indonesia.

Companies producing functional components:

GKD: PT Gemala Kempa Daya,

IGP: PT Inti Ganda Perdana,

TDW: PT Tri Dharma Wisesa,

CHN: PT Chemco Harapan Nusantara,

DSP: PT Dharma Sarana Persada,

PT Daikin Clutch Indonesia,

WEP: PT Wahana Eka Paramitra,

IWG: PT Intindo Wahana Gemilang. 
TABLE III

Four-Wheeled Vehicle Sales and the Astra Group’s Market Share, 1976-95

\begin{tabular}{|c|c|c|c|c|c|c|c|c|c|}
\hline & \multirow{2}{*}{$\begin{array}{l}\text { Unit Sales } \\
\quad \text { (No.) }\end{array}$} & \multicolumn{2}{|c|}{ Astra Group Total } & \multirow{2}{*}{$\begin{array}{c}\text { Toyota } \\
(\%)\end{array}$} & \multirow{2}{*}{$\begin{array}{l}\text { Daihatsu } \\
(\%)\end{array}$} & \multirow{2}{*}{$\begin{array}{c}\text { Nissan } \\
\text { Diesel } \\
(\%)\end{array}$} & \multirow{2}{*}{$\begin{array}{c}\text { BMW } \\
(\%)\end{array}$} & \multirow{2}{*}{$\begin{array}{c}\text { Peugeot, } \\
\text { Renault } \\
(\%)\end{array}$} & \multirow{2}{*}{$\begin{array}{c}\text { Others } \\
(\%)\end{array}$} \\
\hline & & (No.) & $(\%)$ & & & & & & \\
\hline 1976 & 72,438 & 25,534 & 35.3 & 23.0 & 10.1 & - & - & 2.1 & - \\
\hline 1977 & 87,562 & 35,294 & 40.3 & 24.3 & 14.4 & - & - & 1.6 & - \\
\hline 1978 & 103,282 & 43,310 & 41.9 & 28.4 & 12.5 & - & - & 0.9 & - \\
\hline 1979 & 102,994 & 41,456 & 40.3 & 28.0 & 11.9 & - & - & 0.4 & - \\
\hline 1980 & 172,400 & 71,914 & 41.7 & 29.0 & 12.3 & - & - & 0.4 & - \\
\hline 1981 & 201,809 & 83,694 & 40.3 & 27.5 & 12.2 & - & - & 0.6 & - \\
\hline 1982 & 188,780 & 82,506 & 43.7 & 25.8 & 16.7 & - & - & 1.3 & - \\
\hline 1983 & 151,858 & 61,128 & 40.3 & 21.1 & 17.8 & - & - & 1.4 & - \\
\hline 1984 & 152,331 & 69,877 & 45.9 & 19.5 & 25.4 & - & - & 1.0 & - \\
\hline 1985 & 144,297 & 63,604 & 44.1 & 19.6 & 22.9 & 0.5 & 0.1 & 0.9 & - \\
\hline 1986 & 162,091 & 68,454 & 42.2 & 18.0 & 22.3 & 0.7 & 0.6 & 0.6 & - \\
\hline 1987 & 159,712 & 76,621 & 48.0 & 24.0 & 22.4 & 0.6 & 0.5 & 0.5 & - \\
\hline 1988 & 158,555 & 74,246 & 46.8 & 26.8 & 18.1 & 0.9 & 0.7 & 0.3 & 0.0 \\
\hline 1989 & 179,231 & 86,766 & 48.4 & 28.8 & 16.4 & 1.6 & 1.0 & 0.4 & 0.2 \\
\hline 1990 & 275,524 & 145,734 & 52.9 & 26.4 & 20.4 & 2.3 & 1.1 & 0.6 & 2.1 \\
\hline 1991 & 263,073 & 144,979 & 55.1 & 28.9 & 16.6 & 1.6 & 1.2 & 0.3 & 6.4 \\
\hline 1992 & 171,865 & 98,288 & 57.2 & 27.3 & 15.5 & 1.3 & 0.8 & 0.3 & 12.0 \\
\hline 1993 & 210,679 & 108,833 & 52.8 & 24.3 & 15.0 & 0.7 & 0.7 & 0.2 & 11.9 \\
\hline 1994 & 321,907 & 172,449 & 55.2 & 24.7 & 18.1 & 1.2 & 0.9 & 0.2 & 10.1 \\
\hline 1995 & 378,697 & 192,573 & 54.5 & 25.5 & 15.8 & 0.9 & 0.8 & 0.2 & 11.3 \\
\hline
\end{tabular}

Source: Based on Toyota-Astra Motor materials.

Notes: 1. "Other" refers to Fiat (from 1988) and Isuzu (from 1990).

2. - indicates prior to the acquisition of sole agencies by the Astra Group.

whereas the integration of functional components was enabled by preferential license allocation from the government. These horizontal and vertical integrations can be seen as a corporate behavior of Astra that made use of its own position as a top automaker in Indonesia.

Stage (4) is the beginning of exports. Following the sharp decline of crude oil prices in 1983, the emphasis of the government's economic policies shifted from import-substitution to export-oriented industrialization aimed at stimulating manufactured exports. Exports of manufactured products rose sharply from 1987 on. The machinery segment of the Astra Group, which had been a typical import-substitution industry, commenced exports of certain parts (indicated by $\square$ in Table II), such as batteries and spark plugs in 1984-85 as well as Toyota $5 \mathrm{~K}$ engines and Komatsu forklift frames in 1988-89. However, the selection of export items, export volume, and destinations, generally depended on the global strategies of the Japanese principals that were the parent companies of the joint ventures. Therefore, apart from these exports by the existing joint ventures, the Astra Group set up export-oriented machinery joint ventures with foreign companies that were newly coming into Indonesia as part of their relocation of production base. Examples of 
this are the group's production of forging parts for heavy machinery in collaboration with Hokuriku Kogyo of Japan, and some electronics of which import substitution had been delayed, such as TV set assembly with LG (Lucky Goldstar) of the Republic of Korea and semiconductor assembly with a Singaporean firm.

The Astra Group since 1969 had been centering on growth in the machinery industries as outlined above. The noteworthy characteristics of the Astra Group's machinery industry are that the group, in total conformance with national policies, pursued an import-substitution process, that the group utilized the union with Japanese capital and technology in that process, and that the group initiated production integration as the leader of the industry.

\section{THE MODERNIZATION OF MANAGEMENT SYSTEM}

Next, we will focus on the Astra Group's management system, which were shaped in connection with the group's business development. We will first examine the group's organization and controlling system, second its financial management and fund procurement, and third its managers.

\section{A. Organization, Controlling System, and Corporate Philosophy}

1. Divisional system and holding company system

From the earliest stage of the group formation, the Astra Group set up a headquarters at the core of group's ownership and management structures. What typifies the headquarters function in terms of management is the divisional system.

The divisional system became a common trend in Indonesian business groups from the end of the 1980s; however, in the case of the Astra Group, the group had established its first "divisions" (divisi) within AI by 1969, which was extremely early. They were the Toyota Division, the Heavy Machinery Division, and the Honda Motorcycle Division.

These three divisions were originally established to hold sole agencies. Later, the sole agencies were transferred from AI to newly established affiliated companies (i.e., PT Toyota-Astra Motor, PT United Tractors, and PT Federal Motor respectively). Then the functions for each division shifted to domestic sales firstly, and to the coordination of the affiliated companies concerned secondly. Domestic sales were dominant until the mid-1970s, when AI put forth a plan "AI aiming to be a holding company" in 1975. Under the first stage of the plan, AI's varied sales operations were to be transformed into separate affiliated companies, and the resulting affiliated companies were to be grouped into clusters of affiliated companies on the basis of their business sector. Under the second stage of the plan, the group directors who were assigned the role of coordinating each cluster of affiliated companies were to be positioned in AI [5; Vol. 4, No. 4, 1975, p. 17]. The "holding company" referred to here did not simply have ownership functions but 
also indicated that AI was specialized in coordinating and controlling the subsidiary management. This plan provided the framework for AI's management control functions by means of divisional organization up to the beginning of the 1980s. AI's specialization of control functions was closely related to the proliferation of affiliated companies and efforts to unify operations as a whole. Already by 1983 , AI held thirty-six directly invested affiliated companies.

The above process is the direct opposite of the process experienced by most Indonesian business groups, which introduced the divisional system starting from the end of the 1980s. In most business groups, affiliated group companies were originally managed by each management organization within the company. After management reforms, a board of directors was established at the apex of the group to consolidate the management of the group as a whole, and a divisional structure was set up below the board of directors. However, the Astra Group, having established a divisional structure right from the beginning, gradually transformed the functions from agency holding, sales services to subsidiary control. The fact that it had already assumed a divisional structure in the initial period of the group's formation led to the following two effects among others, in its group management perspective. First, investments into a wide range of unrelated industries, as was a common practice among many local companies in the 1970s, was prevented at least under AI's umbrella. Secondly, the vertical relationship between each of AI's divisions and its affiliated companies developed through the exchange of personnel and information, as exemplified by the establishment in 1972 of the group's inhouse newsletter Astra. This led to create centripetal forces within the group.

\section{Controlling system called Astra TQC}

Astra total quality control (ATQC) was introduced in 1983 as the concept for the Astra Group's method of management control. Total quality control (TQC), which refers to comprehensive or company-wide quality control, aims to raise not only quality control at the production site but also the quality of non-production tasks such as sales, accounting, planning, and development. This concept, which was widespread in Japan during the 1970s, was applied to the management of the Astra Group, resulting in ATQC.

ATQC was born from the spread of the QC movement in each group company. QC circle activities were first introduced in the mid-1970s into Japanese joint companies belonging to the Toyota and Honda groups. Then the activities spread to non-joint venture automotive firms such as PT Gaya Motor. Within these individual non-joint venture companies, the scope of QC broadened in 1980 to become TQC. TQC contests and training courses were carried out within the Astra Group, and it won praise from the government as "Indonesia's pioneer of TQC" [5; Vol. 13, No. 1, 1984, p. 9]. The designation ATQC, referring to TQC as practiced in the group's operating companies, emerged in 1983, but was at that time nothing more than a transplant of Japanese TQC. 
From 1983, ATQC was applied to the group-level management. The term came to define such regular managerial meetings as weekly executive meetings at AI, monthly meetings of division managers, and semi-annual (at present annual) "leaders meetings" (rapat pemimpin) including managers of affiliated companies. At AI the previous year's business results from each division and the business plans for the next two years (at present the next five years) are composed using a standard format and are used as checking materials at regular managerial meetings. This controlling system of management has come to be called Astra TQC at the groupwide level. ${ }^{6}$

\section{Corporate philosophy}

In 1983, the same year that Astra TQC was introduced, the four principles of corporate philosophy "Catur Dharma," which form the foundation of corporate culture of the Astra Group, were promulgated.

William explained his idea on the group's management philosophy in a 1975 newsletter in the following terms. "From the founding of AI to the present, we have always continued to adhere to one philosophy. That is, the company can grow and develop successfully if all personnel are diligent, cooperative with each other, and have a sense of belonging to the company, and if all the personnel, the public, and the shareholders can perceive and enjoy the fruits of the company's success" [5; Vol. 4, No. 4, 1975, p. 18]. The keywords here are diligence, cooperation, and a sense of belonging. English is used for the term "sense of belonging," which means that it is an imported concept. These keywords indicate influence of Japanese corporate culture with which Astra has had close contact with through joint ventures.

Subsequently, the four principles of the Astra Group were created by adding the two elements consisting of contribution to the nation and service to customers. The principles were first expressed in Indonesian on the twenty-sixth anniversary of the founding of AI, by the then-president director of AI, Benyamin in February 1983, and then were made into the following slogans in Indonesian and English [5; Vol. 12, No. 1, 1983, pp. 4-7]:

1. To be an asset to the nation,

2. To provide the best service to our customers,

3. To respect the individual and develop teamwork,

4. To continually strive for excellence.

The four principles not only appear on the front page of AI's annual report but are also kept by each affiliated company in the form of a pledge and are distributed to employees and affiliated people at a variety of group activities and awards.

The explanations attached to the pledge do not use the previously mentioned term in English, "sense of belonging," but a substituted Indonesian phrase meaning "feelings of affection and responsibility to carry out business activities" (kecintaan

\footnotetext{
${ }^{6}$ Based on interviews conducted by the author with the public relations division in AI.
} 
dan rasa tanggungjawab menyelenggarakan usaha), in which one can trace assimilation of the imported concept. Both Astra TQC and the four principles of philosophy go back to systems and concepts transplanted from Japan but, have acquired their own meanings through the process of being applied by the Astra Group.

It was in this way up to the mid-1980s that the basic framework of the group's organization and controlling system were formed, and this framework has endured to the present.

\section{B. Financial Management and Fund Procurement}

\section{The modernization of financial management}

AI probably was the first domestic private company in Indonesia to produce audited financial statements and was, as such, Indonesia's pioneer.

William invited A. L. Vijverberg, a Dutch expert in financial management, to AI in 1972. At that time, Indonesia was almost completely unaware of the value of audited financial reports. At Mr. Vijverberg's guidance, AI brought its 1972 financial report to Drs. Utomo Mulia \& Co., the Indonesian subsidiary of the international auditors SGV, which refused to certify the audit. By the following year, however, the financial report had benefited from the effects of Mr. Vijverberg's assistance and it was certified unconditionally by the same auditors [1, p. 111]. Subsequently AI added three Dutch experts to its staff, who proceeded to consolidate the financial management. The reason for turning to Dutch experts for assistance was that Indonesian corporate accounting followed Dutch accounting methods. However, the fact that the completed financial reports exactly followed the format of the financial reports issued by Japanese-affiliated companies within the group indicates that the contact with Japanese companies triggered Astra's financial reform.

\section{The development of measures of fund procurement}

Based on orderly financial management, the Astra Group developed measures of procuring funds from external sources. The main measures used are the five cited below (Table IV).

The first consisted of borrowing from the Jakarta branches of U.S.-affiliated banks. When in 1974, the Astra Group experienced a crisis of debt repayment failure in the real estate business, ${ }^{7}$ the Jakarta branches of three U.S.-affiliated banksAEIBC (American Express International Banking Corporation), FNCB (First National City Bank), and Chase Manhattan Bank, N.A.-which had high regard for Astra's financial reports, advanced loans to AI, thereby helping it to weather the

\footnotetext{
${ }^{7}$ PT Indonesia Land, a joint venture with Ibnoe Sutowo, then-President Director of Pertamina (Indonesia's state-owned petroleum company) and other partners, was faced with repaying liabilities totaling U.S.\$4 million.
} 
crisis [(1) in Table IV]. Since that time, AI has continued to maintain a customer relationship with those U.S. banks that, until then, had only provided loans to foreign-affiliated companies.

The second consisted of procuring funds from international capital markets. In 1981, AI was the first Indonesian company, including state-owned companies, to issue bonds on international capital markets [(2) in Table IV]. As overseas funds procurement by Indonesian companies increased sharply in the period 1988-90, AI also secured a wide range of syndicate loans and issued a variety of bonds [(4), (6), (12) in Table IV]. Considered a blue-chip Indonesian corporation, AI benefited from low spreads of 0.5-1.0 per cent and was able to procure funding at interest rates around 2 per cent lower than domestic borrowings even with the addition of swap costs to avoid exchange rate risks (the state commercial banks' lending interest rate was 20-21 per cent in 1989). ${ }^{8}$

The third was the development of new domestic funds procurement methods. In 1988, AI was the first purely private company to issue bonds on the domestic bond market on which only three government institutions ${ }^{9}$ had hitherto issued bonds since the market's launch in 1983 [(5) in Table IV]. In 1990, AI became a recipient of the first syndicate loan lead-managed by a domestic private commercial bank, the Bank Niaga [(13) in Table IV].

The fourth measure was the procurement of funds from the domestic stock market. AI itself was listed on the stock market in 1990, following the listing of two blue-chip operating companies under the Astra Group [(8), (9), (11) in Table IV]. This remained the sole instance of the holding company of a business group being listed until 1994. Although the listing of a business group's holding company has an advantage of channeling the funds procured throughout the group's undertakings, it also has disadvantages such as requiring information on the entire group to be made public, lowering the holding ratio by the founding family, and allowing the intervention of third parties into the management of the group. For these reasons, many Indonesian business groups hold the line at listing only blue-chip operating companies and not the holding company. However, the Astra Group's two-tiered structure composed of AI and non-AI sectors, played a major role in what the group pioneered. In other words, the AI's affiliates were basically foreign joint ventures and blue-chip companies that produced audited consolidated financial reports and had already secured a great deal of confidence from foreign financial institutions in the 1980s. It therefore was not disadvantageous for AI to make public, information pertaining to that sector.

\footnotetext{
${ }^{8}$ Based on interviews conducted by the author with personnel in AI's domestic finance division.

9 Three companies: BAPINDO (Bank Pembangunan Indonesia), a state development bank; PT Jasa Marga, a state-owned road construction and management company; and PT Papan Sejahtera, a semi-government housing development company.
} 
TABLE IV

Fund Procurements by the Astra Group, 1974-93

\begin{tabular}{|c|c|c|c|c|c|c|}
\hline No. & Year & Procured by & Method & Source & \multicolumn{2}{|c|}{ Amount } \\
\hline (1) & 1974 & $\begin{array}{l}\text { PT Astra } \\
\text { International, Inc. }\end{array}$ & Short-term loan & $\begin{array}{c}\text { Jakarta branches } \\
\text { of U.S. banks }\end{array}$ & Rp 2.69 & billion \\
\hline (2) & 1981 & $\begin{array}{l}\text { PT Astra } \\
\text { International, Inc. }\end{array}$ & $\mathrm{FRN}^{\mathrm{a}}$ & $\begin{array}{l}\text { Singapore: Asia- } \\
\text { dollar market }\end{array}$ & U.S.\$25 & million \\
\hline (3) & 1983 & PT United Tractors & Syndicated loan & $\begin{array}{l}\text { Singapore: Asia- } \\
\text { dollar market }\end{array}$ & U.S.\$45 & million \\
\hline (4) & 1988 & $\begin{array}{l}\text { PT Astra } \\
\text { International, Inc. }\end{array}$ & Syndicated loan & West Germany & DM 50 & million \\
\hline$(5)$ & 1988 & $\begin{array}{l}\text { PT Astra } \\
\text { International, Inc. }\end{array}$ & Bonds & Jakarta stock market & $\operatorname{Rp} 60$ & billion \\
\hline (6) & 1989 & $\begin{array}{l}\text { PT Astra } \\
\text { International, Inc. }\end{array}$ & $\mathrm{NIF}^{\mathrm{b}}$ & Hong Kong & U.S.\$100 & million \\
\hline (7) & 1989 & $\begin{array}{l}\text { PT Astra } \\
\text { International, Inc. }\end{array}$ & RUF $^{\mathrm{c}}$ & Indonesia & $\operatorname{Rp} 40$ & billion \\
\hline (8) & 1989 & PT Astra Graphia & Stock listing & Jakarta stock market & $\operatorname{Rp} 26.3$ & billion \\
\hline (9) & 1989 & PT United Tractors & Stock listing & Jakarta stock market & Rp 59.6 & billion \\
\hline (10) & 1989 & $\begin{array}{l}\text { PT Astra } \\
\text { International, Inc. }\end{array}$ & $\begin{array}{l}\text { Disposal of } \\
\quad \text { shareholdings } \\
\quad+\text { loans }\end{array}$ & $\mathrm{IFC}^{\mathrm{d}}$ & U.S. $\$ 37.5$ & million \\
\hline (11) & 1990 & $\begin{array}{l}\text { PT Astra } \\
\text { International, Inc. }\end{array}$ & Stock listing & Jakarta stock market & $\operatorname{Rp} 446$ & billion \\
\hline (12) & 1990 & $\begin{array}{l}\text { PT Astra } \\
\text { International, Inc. }\end{array}$ & Syndicated loan & $\begin{array}{l}\text { Tokyo offshore } \\
\text { market }\end{array}$ & U.S.\$50 & million \\
\hline (13) & 1990 & $\begin{array}{l}\text { PT Astra } \\
\text { International, Inc. }\end{array}$ & Syndicated loan & Indonesia & Rp 140 & billion \\
\hline (14) & 1990 & $\begin{array}{l}\text { PT Raharja Sedaya } \\
\text { Finance }\end{array}$ & Syndicated loan & Hong Kong & U.S.\$75 & million \\
\hline$(15)$ & 1991 & $\begin{array}{l}\text { PT Astra } \\
\text { International, Inc. }\end{array}$ & Convertible bonds & Jakarta stock market & $\operatorname{Rp} 50$ & billion \\
\hline
\end{tabular}


TABLE IV (Continued)

\begin{tabular}{|c|c|c|c|c|c|}
\hline No. & Year & Procured by & Method & Source & Amount \\
\hline (16) & 1991 & $\begin{array}{l}\text { PT Astra } \\
\text { International, Inc. }\end{array}$ & Convertible bonds & $\begin{array}{l}\text { Luxembourg stock } \\
\text { market }\end{array}$ & U.S.\$125 million \\
\hline (17) & 1992 & $\begin{array}{l}\text { PT Astra Sedaya } \\
\text { Finance }\end{array}$ & Syndicated loan & Indonesia & Rp 50 \\
\hline (18) & 1992 & $\begin{array}{l}\text { PT Astra Sedaya } \\
\text { Finance }\end{array}$ & $\begin{array}{l}\text { Disposal of } \\
\text { shareholdings }+ \\
\text { convertible bonds }\end{array}$ & GECC $^{\mathrm{e}}$ & U.S.\$49 million \\
\hline (19) & 1993 & $\begin{array}{l}\text { PT Mitracorp } \\
\text { Pacificnusantara }\end{array}$ & Convertible bonds & $\begin{array}{l}\text { Consolidated } \\
\text { Resources Ltd. }\end{array}$ & U.S.\$21 million \\
\hline
\end{tabular}

Source: Based on interviews in August 1990 with Astra International Finance Division; [5, various issues]; [4, 1993 edition]; and various other materials.

a Floating rate note.

Note issuance facility.

Revolving underwriting facility.

d World Bank-affiliated investment company.

General Electric-affiliated investment company

f Singapore-based multinational investment company. 
The fifth method was to obtain equity investment from the International Finance Corporation (IFC) and other foreign investment institutions [(10), (18), (19) in Table IV]. Having secured funding, companies with holding functions such as AI and PT Astra Sedaya Finance would then channel the funds to their affiliated companies.

Since the time when most private Indonesian companies were dependent on the state commercial banks for securing funds, the Astra Group, based on the confidence foreign and domestic financial institutions had in its modernized financial management, has sought to pioneer precedent-setting fund procurement routes at a lower cost and for longer periods.

\section{Managers}

1. The separation of ownership and management in family members

AI was originally established as a company jointly owned by Tjia Kian Tie (referred to below as "Tjia"), who is the younger brother of William, and a friend of Tjia who had no blood relationship. Tjia assumed the presidency, and William's name did not appear in the ownership or management [3, 1957-1117]. It was in April 1970 that AI's ownership was restructured into exclusive ownership by William's relatives. Under the new shareholding structure, 60 per cent of the shares in the company were provided by William (Lily Soeryadjaya, William's wife, provided half of this share until 1973), with the remaining 40 per cent divided into 10 per cent shareholdings among William's eldest son, second son, eldest daughter, and second daughter [3; 1973-537, 1974-180]. This structure remained unchanged for the next eighteen years until 1988.

Here it is important to note that William's blood relatives (other than his children), who played crucial roles in the development of the Astra Group, were excluded from AI's shareholding structure. William's younger brother Tjia, who was the leading figure in the founding of AI, held the position of AI's chairman of the board of commissioners (Komisaris) from April 1970 on. Although William was the president director at the time, many of those involved testify that Tjia was in the forefront leading the actual management team, despite his formal title as chairman of the board of commissioners, and promoted the advance of the Astra Group's main businesses in the first half of the 1970s, including automobiles, heavy machinery, and real estate. Tjia passed away suddenly at the age of 54 in 1979. Tjia's younger brother Ir. Benyamin Arman Suriadjaya (referred to below as "Benyamin," Chinese name Tjia Kian You), held various positions at AI, including director (1971-79), president director (1979-84), and commissioner (1984present). William's nephew, Ir. Theodore Permadi Rachmat (referred to below as "Rachmat," Chinese name Oey Giok Eng), who joined AI in 1972, now holds the position of president director following Benyamin (1984-present).

These three blood relatives were involved in the management of not only AI but 
also many companies in the Astra Group. Table V shows the concurrent management positions held by the main managers of the Astra Group in major group companies. It shows in which companies they held positions on the board of directors (Dewan Direksi), which carries out the day-to-day management, and on the board of commissioners (Dewan Komisaris), which supervises the board of directors. ${ }^{10}$ An examination of the table reveals that Benyamin and Rachmat (Tjia's posts were omitted due to his death) held the most concurrent posts in group companies irrespective of the business sector.

The degree of involvement of William's four children in the management of the Astra Group was far less than the involvement of the above three (Tjia, Benyamin, and Rachmat). William's eldest son and daughter and second daughter became members of AI's board of commissioners after 1979-80 when they returned from studying overseas; however, they were not involved in day-to-day management. Only William's second son, Edwin joined the company as a director. He became vice president in 1990, and was expected to become the next president director.

Thus those who were actually directing the Astra Group's management were William's blood-relative managers without ownership. They participated in the ownership of part of the Astra Group in the broad sense, with owning the individually invested holding companies outside the main group companies shown on the table. Speaking only of AI and its cluster of affiliates, however, a clear demarcation was drawn between William and his children, who were owners, and William's younger brothers and a nephew, who were managers but not owners, even though all were blood related. It is noteworthy that this demarcation was drawn by William himself in 1970 at the very initial stage of formation of the Astra Group. Although Benyamin and Rachmat purchased part of William's holdings in 1988 and became shareholders in AI, the ratio of their holdings was low at 5 and 2.5 per cent, respectively. It may be assumed that William deliberately avoided joint ownership by multiple lines of direct relatives as it may have created an unstable ownership structure.

\section{The distribution of non-blood-related managers}

Seven of the main ten managers cited in Table V are not related by blood to William. These non-blood-related managers show a tendency to be distributed in

10 Under Indonesian company law, each joint-stock company (PT: perseroan terbatas) is obliged to establish both a board of directors and a board of commissioners. The functions of the board of commissioners are not limited to auditing, as in Britain and the United States but the supervision of the duties executed by the board of directors, as in the Netherlands. The articles of incorporation for each company stipulate the capabilities of the board of commissioners, which, in some cases, includes the approval of large investments and fund procurement, the power to suspend directors from duty, and the power to call extraordinary shareholders meetings. Therefore, the importance of the board of commissioners as a management post is in no way inferior to that of the board of directors. 
TABLE $\mathrm{V}$

Concurrent Management Positions Held by the Main Managers of the Astra Group, 1985

\begin{tabular}{|c|c|c|c|c|c|c|c|c|c|c|}
\hline & (1) & $(2)$ & (3) & (4) & $(5)$ & (6) & (7) & $(8)$ & (9) & (10) \\
\hline $\begin{array}{l}\text { Blood-related (B)/ } \\
\text { Non-blood-related (N) }\end{array}$ & B & B & $\mathrm{N}$ & $\mathrm{N}$ & $\mathrm{N}$ & $\mathrm{N}$ & B & $\mathrm{N}$ & $\mathrm{N}$ & $\mathrm{N}$ \\
\hline $\begin{array}{l}\text { University } \\
\text { Ethnic Chinese (C)/ }\end{array}$ & Holland & ITB & n.a. & n.a. & n.a. & ITB & ITB & ITB & n.a. & ITB \\
\hline Pribumi $(\mathrm{P})$ & $\mathrm{C}$ & $\mathrm{C}$ & $\mathrm{C}$ & $\mathrm{C}$ & $\mathrm{P}$ & $\mathrm{P}$ & $\mathrm{C}$ & $\mathrm{P}$ & $\mathrm{C}$ & $\mathrm{P}$ \\
\hline $\begin{array}{l}\text { PT Astra International } \\
\text { Inc. (AI) }\end{array}$ & $\mathrm{K}$ & $\mathrm{k}$ & & & & $\mathrm{k}$ & $\mathrm{D}$ & d & & d \\
\hline Real estate (outside AI) & & & & & & & & & & \\
\hline PT Silga & $\mathrm{D}$ & $\mathrm{d}$ & & & & $\mathrm{k}$ & & & & \\
\hline $\begin{array}{l}\text { PT National Roadbuilders } \\
\text { \& Construction Co. }\end{array}$ & & & & & & D & & & & \\
\hline PT Multi Land & $\begin{array}{l}\mathrm{K} \\
\mathrm{D}\end{array}$ & $\begin{array}{l}\mathrm{d} \\
\mathrm{d}\end{array}$ & $\mathrm{K}$ & & & D & & & & \\
\hline PT Town \& City Properties & $\mathrm{D}$ & $\mathrm{d}$ & $\mathrm{k}$ & & & & & & & \\
\hline PT Indonesia Land & $\mathrm{D}$ & $\mathrm{d}$ & $\mathrm{k}$ & & & & & & & \\
\hline PT Multi Plaza Properties & $\mathrm{D}$ & $\mathrm{d}$ & $\mathrm{K}$ & $\mathrm{k}$ & & & & & & \\
\hline PT Bumi Upaya Griya & & $\mathrm{K}$ & & $\mathrm{k}$ & & $\mathrm{k}$ & & & & \\
\hline PT Grama Sitiung Permai & $\mathrm{K}$ & $\mathrm{k}$ & & & d & $\mathrm{D}$ & & & & \\
\hline
\end{tabular}

Automotive (under AI)

PT Gaya Motor

PT Multi France Motor

PT Kayaba Indonesia

PT Alpha Harapan Nusantara

$\mathrm{D}$

d

PT Menara Alam Teknik

PT Gemala Kampa Daya

PT Tri Dharma Wisesa

PT Inti Ganda Perdana

PT Wahana Eka Paramitra

Heavy equipment (under AI)

PT United Tractors
$\mathrm{D}$
$\mathrm{k}$

\begin{tabular}{l|ll} 
& & \\
& $\mathrm{d}$ & $\mathrm{k}$ \\
$\mathrm{k}$ & $\mathrm{d}$ \\
$\mathrm{d}$ & $\mathrm{d}$ & $\mathrm{D}$ \\
$\mathrm{k}$ & $\mathrm{D}$ & \\
$\mathrm{k}$ & $\mathrm{D}$ & \\
$\mathrm{k}$ & $\mathrm{k}$ &
\end{tabular}
d

WD 
TABLE V (Continued)

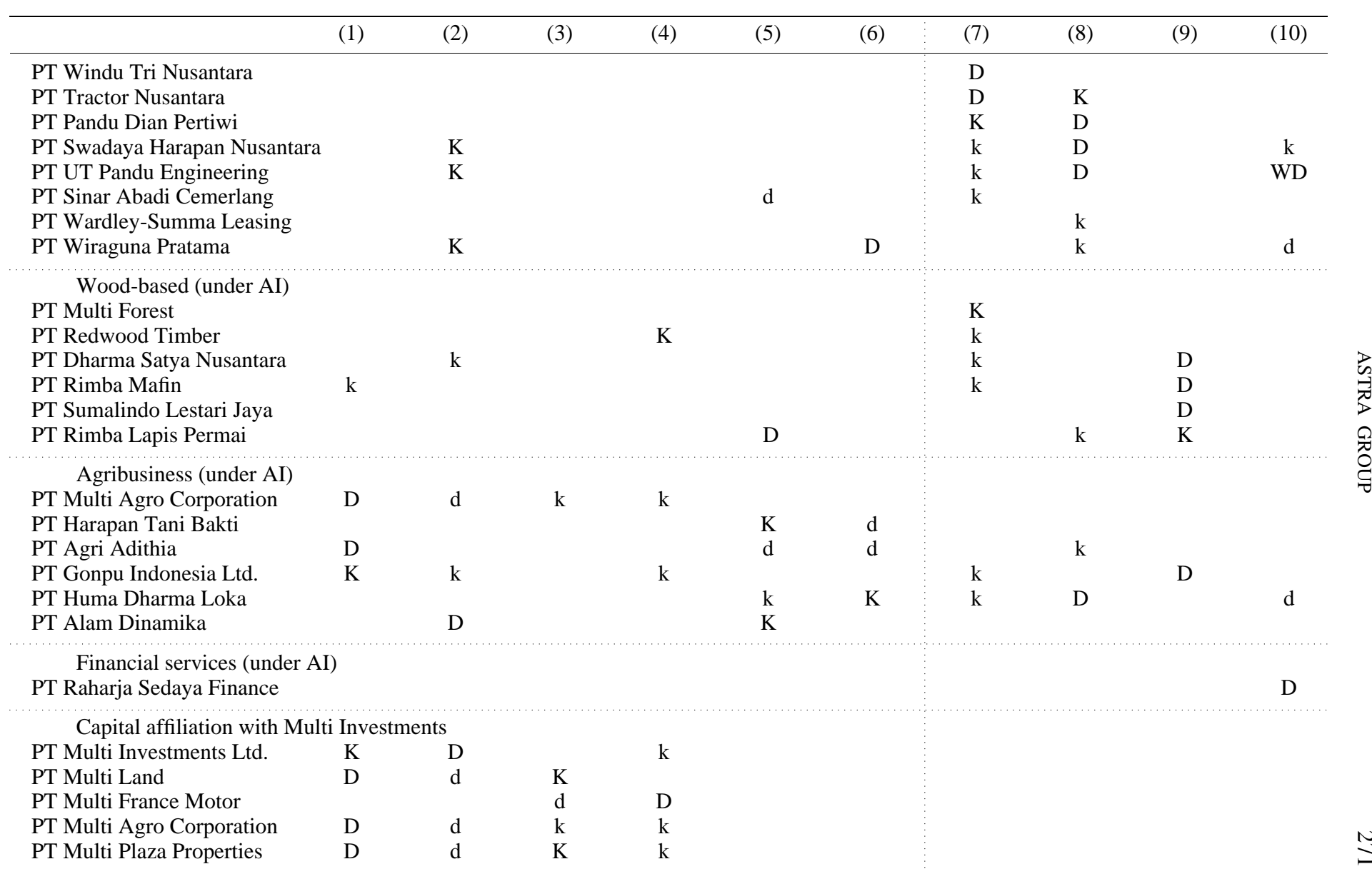


TABLE V (Continued)

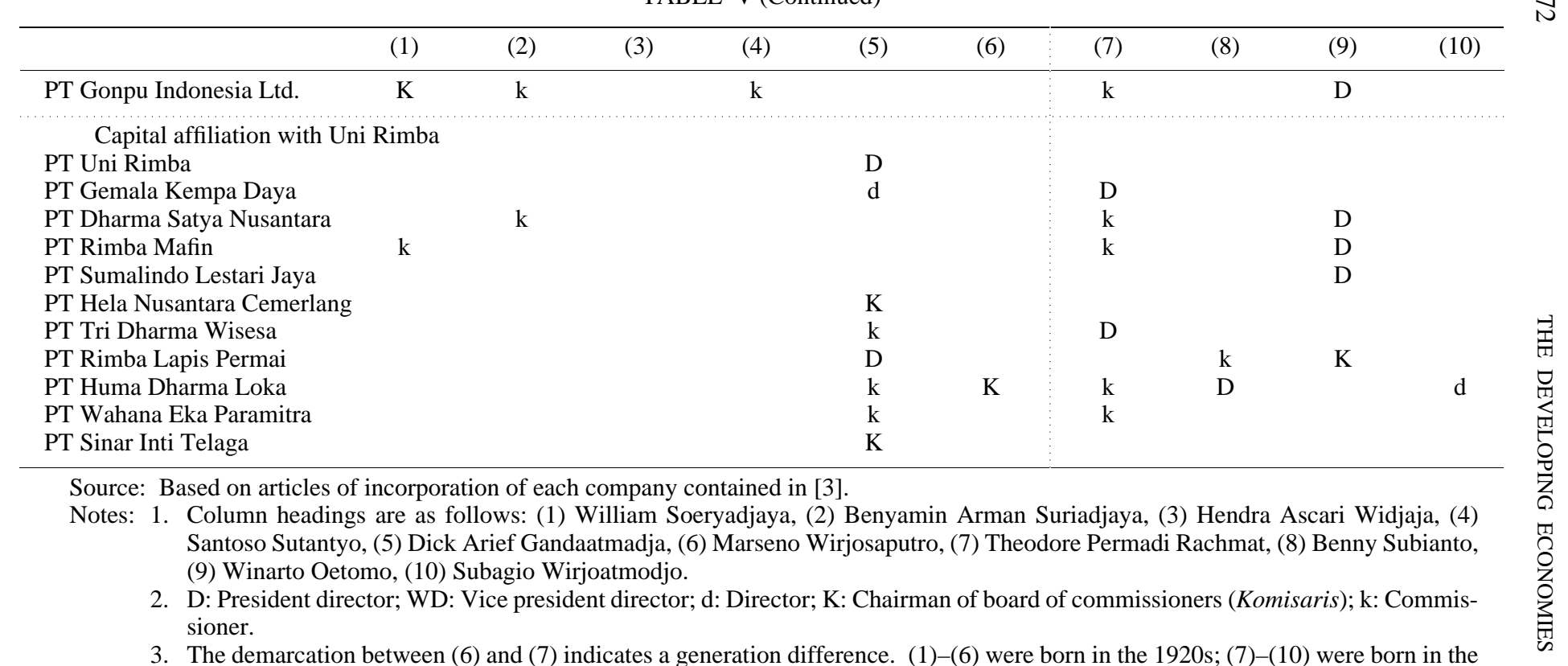

3. The demarcation between (6) and (7) indicates a generation difference. (1)-(6) were born in the 1920s; (7)-(10) were born in the 1940s.

4. ITB indicates the Bandung Institute of Technology and n.a. indicates that information is not available. 
certain industrial sectors or in certain capital affiliations. For example, Hendra Ascari Widjaja (3) and Marseno Wirjosaputro (6) are in real estate, Benny Subianto (8) is in heavy machinery, Winarto Oetomo (9) is in wood-based, Subagio Wirjoatmodjo (10) is in financial services (the last may be difficult to see on the table because there are only a few examples); Santoso Sutantyo (4) and Hendra Ascari Widjaja (3) are in PT Multi Investments Ltd. and its affiliated companies, and Dick Arief Gandaatmadja (5) is in PT Uni Rimba and its affiliated companies. Nonetheless, the distribution of managers in agribusiness is very diverse.

An examination of the birth dates of these seven non-blood-related managers shows that Hendra Ascari Widjaja (3), Santoso Sutantyo (4), Dick Arief Gandaatmadja (5), and Marseno Wirjosaputro (6) were born in the 1920s, while Benny Subianto (8), Winarto Oetomo (9), and Subagio Wirjoatmodjo (10) were born in the 1940s. The former group consists of friends of William. ${ }^{11}$ Out of them, it is said that Dick Arief Gandaatmadja (5), a Sundanese (pribumi, native ethnic Malay) who was born in West Java, played a role of a negotiator with the government in the sectors of wood-based and functional automotive components, where acquiring licenses was of great importance. The latter group, with the addition of Marseno Wirjosaputro (6), includes graduates of the Bandung Institute of Technology (ITB) like Benyamin and Rachmat. Marseno Wirjosaputro (6) graduated from ITB two years before Benyamin, while Benny Subianto (8) and Subagio Wirjoatmodjo (10) graduated from ITB and joined AI about the same time as Rachmat around 1970.

Thus, in the companies under AI, managerial personnel were selected from schoolmates of blood-relative managers and were placed in each industrial sector as key managers. In areas outside of AI, William's associates were entrusted with the management of companies with a single capital affiliation. William himself left management of the group companies to these managers, except for a real estate business established in the first half of the 1970s which he operated as president director ( $\mathrm{D}$ in the table). As chairman of the board of commissioners, he then occupied a position that transcended the everyday management of the individual companies and came to have a symbolic existence in the Astra Group as a whole.

\section{The appointment of pribumi professional managers}

One of the most prominent characteristics of Astra Group management is its active use of pribumi personnel. Of the seven non-blood-related managers in Table $\mathrm{V}$, four are pribumi. In the 1980s the number of professional managers who were hired based on evaluations of their academic background, job career, and capabili-

11 Based on interviews conducted by the author with Mr. N. Kida, who was an old friend of William and at that time AI's representative in Japan. 
ties increased sharply in the Astra Group. An examination of these professional managers indicates that not a small number of pribumi who have high academic credentials such as ITB and the University of Indonesia and/or outstanding job careers were appointed.

Marseno Wirjosaputro [(6) in Table V], who is a pribumi, was the Astra Group's "key man" in hiring and assigning of professional managers. William often said to him "it is no matter whether he or she is pribumi or non-pribumi [meaning ethnic Chinese]" and "there is no guarantee that anyone will perform well just because they are a non-pribumi. What is important is the person" [8, p. 16]. The person who epitomizes the pribumi professional managers of the Astra Group is AI's financial director Rini Mariani Sumarno Soewandi, who was born in 1958. After studying in the United States and working as the vice president of Citibank, N.A.'s Jakarta branch, in a meteoric rise she became a director at AI only one year after joining the company. The appointment of pribumi managers also applies to AI's affiliated companies. At PT United Tractors, for example, more than 90 per cent of the managerial personnel are pribumi [8, p.16].

The employment policy of the Astra Group contrasts with the policies of the Salim Group and the Sinar Mas Group, which like Astra are high-ranking Indonesian business groups. At the Salim Group and the Sinar Mas Group, many of professional managerial personnel are ethnic Chinese, who in some cases are proficient in Mandarin Chinese (putong hua) in addition to Indonesian and English. In recent years even foreign managers are increasing. In contrast, there is no need for the Chinese language in the corresponding managerial personnel at the Astra Group, even in the case of ethnic Chinese, as the members of the founding family do not speak Chinese. The founders of the Salim Group and the Sinar Mas Group are first-generation ethnic Chinese who were born in China, whereas William was a seventh-generation ethnic Chinese. The difference is reflected in personnel appointment policies.

Now let us make an orderly review of the analysis so far. The Astra Group, which traces its formation as a business group back to the beginning of the 1970s when AI acquired a number of sole agencies and joint-venture partnership, began at the same time the modernization of its management system. This is to say that the divisions that had been established to hold sole agencies were gradually transformed into group headquarters with functions to coordinate affiliated companies. The production of audited financial reports subsequently facilitated access to foreign banks and the development of a variety of fund procurement measures tapping domestic and foreign financial markets. Also in the same period of the early 1970s, AI was reorganized into exclusive ownership by the founding family. However, this exclusive ownership did not extend to family control in the sphere of management, and this conversely engendered a distinction between those blood relatives who concentrated on ownership and those blood relatives who concentrated on 
management. The latter group of blood relatives encouraged the appointment of non-blood-related managers, including pribumi, and the effect was a tendency to establish a demarcation between ownership and management. The result was the encouragement of the modernization of the management system by a management team, essentially of blood-related managers and supported by non-blood-related managers.

\section{The Management System after the Divestiture of Family Ownership}

\section{Results of the Summa crisis}

The reason why the founding family divested itself of its AI holdings was due to the financial troubles of the family business known as the Summa Group. The Summa Group experienced rapid growth in 1989 and 1990 in the banking and real estate. However, the Bank Summa, which was in charge of the Summa Group's internal finances, encountered severe financial problems which culminated in November 1992, when the bank failed to honor a note in a rupiah clearing house. (The bank was suspended operations and liquidated in December 1992.) William was forced to dispose of all the family-held shares in AI on the stock market to make preferential repayment of debts, since he had borrowed rescue funds for Summa, putting up the family's shares in AI as security. ${ }^{12}$

Figure 3 shows the changes in AI's ownership structure. Following this period of exclusive ownership by members of the founding family (William and his four children), which lasted eighteen years from 1970, the blood-related managers and the IFC came to be the new shareholders, whereupon AI was listed on the stock exchange; however, members of the founding family still retained 77 per cent ownership. Following the disposal of family-held shareholdings, AI shifted to a multiple ownership structure consisting of five types of shareholders: (1) large domestic private capitalists (roughly ten business groups such as Barito Pacific, Napan, Salim, Sinar Mas, and banks); (2) government financial institutions (a government underwriting institution, state commercial banks, and their pension funds); (3) foreign capitalists (Toyota Motor Co., IFC, and foreign financial institutions); (4) the investing public; and (5) AI managers and employee organizations.

Nonetheless, the management team that carried out the day-to-day management remained in place despite the changes in ownership. Of course, William and his four children had resigned all managerial positions by March 1993. The board of commissioners was reshuffled to include new members consisting of representatives of the government, state banks, and the business groups that were the new shareholders. However, the board of directors in charge of actual management re-

12 Daulay et al. [2, pp. 33-35] refer to the political context as one of the reasons why the Bank Summa was not rescued by the government and the founding family was forced to divest itself of its holdings in AI. They point out that William took wrong action when President Suharto suggested the owners of big business groups to sell 25 per cent of their own shares to cooperatives. 
Fig. 3. Changes in the Ownership Structure of PT Astra International, 1970-93

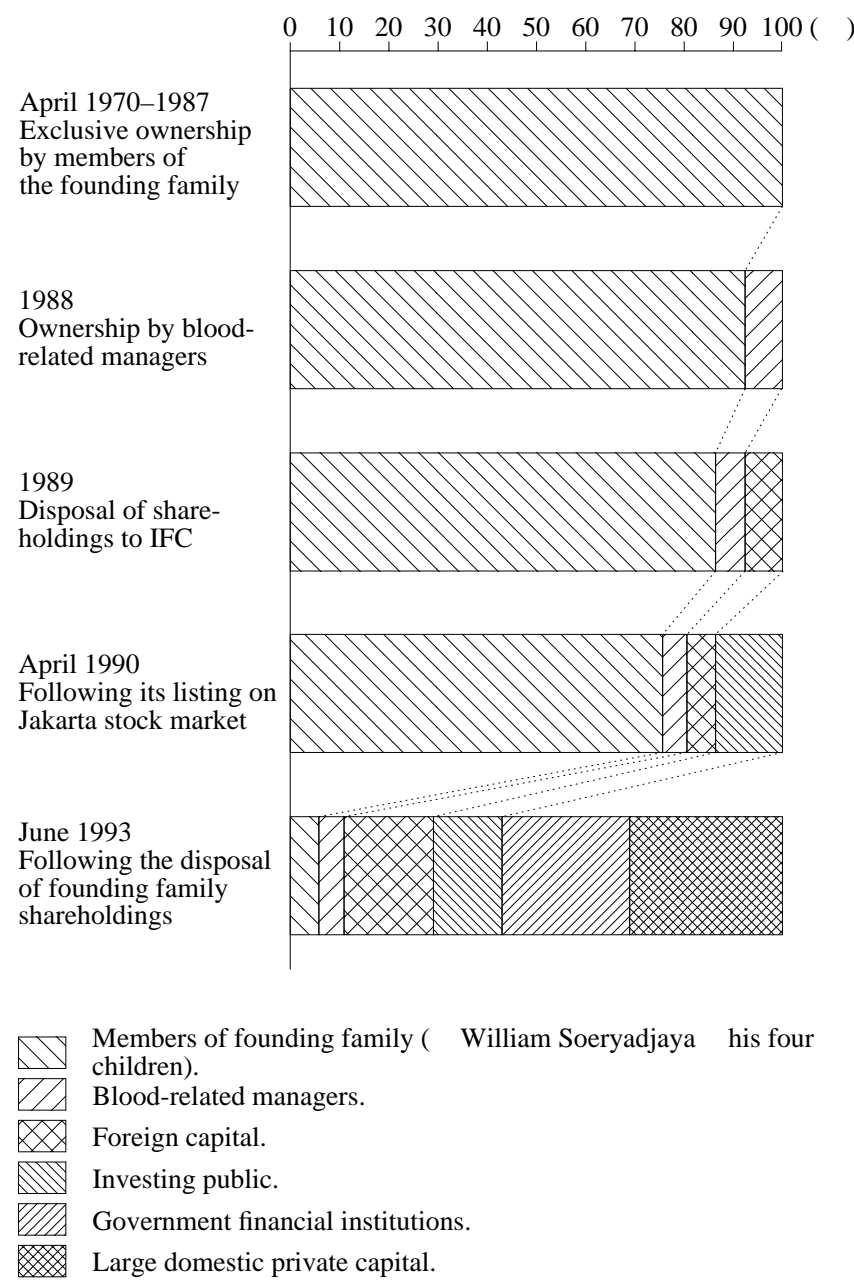

Source: [3, 1973-537], [7; pp. 5, 64-65], and "Lampiran Siaran Pers PR Division Tanggal 22 Juni 1993" [Materials distributed at PR Division press conference on June 22, 1993] in [5; Vol. 22, No. 2 (1993), p. 11].

mained in place with the exception of the second son Edwin, who had been vice president. Two blood-related managers, William's nephew Rachmat, who was the president, and his brother Benyamin, who was the commissioner, also remained in place. It could be possible to take the view that family management continued if they are considered to be representatives of the founding family. However, the 
managers of the Astra Group simply recognize them as the apex of the managerial team which they themselves belong to.

During the Summa crisis, differences frequently appeared between the founding family, whose priority was to rescue Summa, and the Astra management team, whose priority was to minimize damage to the health of the Astra Group. ${ }^{13}$ The two blood-related managers took the position of being representatives of the Astra management team. The demarcation between William's children, who were direct descendants, and his younger brother and nephew, who had a collateral family relationship, which had been drawn during the process of formation of the Astra Group, became decisive at this stage. The Astra management team regarded William's family as being limited to his two sons and two daughters, and treated brother and nephew as representatives of management.

Facing the family's disposal of its AI shareholdings AI's public relations division distributed within $\mathrm{AI}$ and its affiliated companies a memorandum stating that operations would continue without interruption. Guidelines were also set for answering the media in an effort to unify all information in the group. This fact indicates the independence of the management from the ownership. It can be said that from the Summa crisis the management of the Astra Group experienced a need to be actually independent from the ownership.

\section{Current status of group management}

What are the effects of the founding family's disposal of its AI shareholdings on the awareness of the managers, the management system, and group business of the Astra Group?

In regards to manager awareness, it should be emphasized that many of the professional managers interviewed by the author did not interpret the divestiture of ownership by the founding family as a negative factor. ${ }^{14}$ While admitting that "this is the first case in Indonesia," that the founding family no longer possesses the ownership of a large business group, they profess no great worries about the future of Astra, which "has always been the precedent-setter." This attitude rests on their perception that "Astra is no longer a family business but has become a true public company."

Almost no changes are visible in the management system. The Astra management team continues to follow the "four principles of the corporate philosophy;" Astra TQC, which controls the group's overall activities during the year; the

13 For example, AI's management team announced in May 1992 William's intention to dispose of his personal holdings of AI shares (see the newspaper Angkatan Bersenjata, dated May 22, 1992). However, William did not in fact sell off his shares; instead the shares became collateral for the loan rescue package.

14 Based on interviews with a number of Astra Group managers conducted by the author in August 1993. 
weekly meeting of the board of directors at AI; the monthly divisional meetings; the annual leaders meeting of the Astra Group; the recruitment system that hires at one time a batch of new university graduates for the entire group; and the training system carried out at the Astra Training and Education Center.

The greatest concern was about its effect on the group's businesses. If confidence in the Astra Group were to decline, the group would experience difficulty in procuring new funds, and this would hamper the group's business operations. However, AI's success in the procurement of funds totaling Rp 980 billion, consisting of the issuance of new shares in December 1993 and the issuance of bonds in January 1994, swept away such concerns. New investments undertaken since 1993 include the casting of automobile transmission components, mold production in a Japanese joint venture, and the telephone network construction in Sumatra in collaboration with France Telecom. New plans announced, include the production of air conditioners and washing machines in collaboration with Lucky Goldstar, the production of Indonesia's first medium-density fiberboard, and a paper and pulp project in collaboration with Siam Cement of Thailand.

The disposal of the founding family's shareholdings has not had serious negative effects on the business of the Astra Group, at least as far as these developments are concerned. In fact, the divestiture of ownership by the founding family has been a crucial factor in increasing the awareness of the group's managers who play the leading roles.

\section{CONCLUSION}

During the process of formation of the Astra Group from the beginning of the 1970s, the group, with the machinery industry as the foundation of its business, proceeded in group production integration which contained the "union" with Japanese capital and technology. At the same time, the group created a modernized management system, preceding the management reform that swept through Indonesia some ten years later, that included the formation of group headquarters derived from the establishment of divisions as well as the development of new measures of fund procurement starting from the preparation of financial reports. Paralleling these processes, a separation between ownership and management of the group took place among the William's blood relatives.

Why did the Astra Group take the lead in the modernization of its management? One can see that the reason is a combination of the following three factors applying to the group.

The first factor is that the founder, William, belonged to the so-called peranakan ("Indonesian-born ethnic Chinese"), who had already lived in Indonesia for generations and had put down deep roots in the country. This is evident from a comparison with the founders of the Salim Group and the Sinar Mas Group, who are 
first-generation ethnic Chinese (totok). For example, first-generation ethnic Chinese, who speak Fukienese or Mandarin Chinese, initially took advantage of transnational funds provided by other ethnic Chinese. In contrast, William and his top managers, who were peranakan did not have access to such funds, sought instead to arrange joint ventures with foreign capital and to procure funds from capital markets relying on confidence generated by Astra's modernized financial management. In the area of personnel appointment, the Salim Group and the Sinar Mas Group sought to gather a group of capable professional managers focused largely on ethnic Chinese regardless of nationality. In contrast, the Astra Group emphasized the hiring and promoting of pribumi managers with outstanding academic and job careers. In contrast to most of the business groups owned by ethnic Chinese, whose management generally is considered to be closed to outsiders, the Astra Group aimed at management open to the pribumi society. The Astra Group always tried to appeal Indonesian society for support with the first principle of its corporate philosophy - "To be an asset to the nation"-as well as the fostering of human resources and the creation of employment. These policies, rather than being based on active motives such as modernizing management, may well have been created from the circumstances of the peranakan, who had already lost Chinese sociocultural background, although they were identified as being ethnic Chinese, and who had to live in Indonesian society.

The second factor was the "union" with Japanese firms in the machinery, and especially the automobile industries. The automobile industry may be regarded as the most technology-intensive industry among the foreign capital-affiliated industries that flowed in Indonesia in the 1970s. It required comprehensive technology, including not only production technology but production-control and management-control technology as well. The businesses of the Astra Group started from transplantation of production technology by Japanese firms in the automobile industry. The initial transplants of technology took place at the production sites of Japanese-affiliated companies and spread from production technology to quality control and to total quality control. The Astra Group extended the technology to non-Japanese-affiliated group companies and also applied it to the management of the entire group. It can be thought that the group's intimate contacts with the management technology of Japanese firms triggered the introduction of the divisional system, the modernization of financial management, and the search for a corporate philosophy as a foundation for group management in the initial stage of its development at the beginning of the 1970s. The Astra Group first studied Japanese-style management technology incorporated in a wide range of areas of corporate management, and finally applied and modified it to create Astra's own management system.

The third factor is the existence of nonownership managers. As this paper has shown, William's two brothers and nephew were positioned in AI and its affiliated 
companies as managers without ownership in the early 1970s. Centered around this core of three blood-related managers, the Astra Group's top management team including non-blood-related and pribumi managers was then formed. This group of nonowner managers became the recipients of the above-stated two factors- the policies William created from peranakan circumstances and management technology transplanted from Japanese firms. They adjusted these factors so as to create the Astra Group's management system by the mid-1980s. After the incident of the founding family's disposal of its shareholdings, nonowner managers came to be crucial members of the Astra Group. In reality, however, nonowner managers, either blood-related or non-blood-related, had existed since the beginning of the 1970s, and acted as the members to take in and adjust the above factors and to operate and develop the management system. Due to their efforts, the Astra Group had already changed into a corporate organization which did not rely only on the individual endowments of the founder.

\section{REFERENCES}

1. Chowdhury, A, "Corporate Leader of the Year: William Takes Astra Back to Grassroots," Asian Finance (Hong Kong), Vol. 9, No. 11 (November 15, 1983).

2. Daulay, A. H., et al. William Soeryadjaya: Kejayaan dan Kejatuhannya [William Soeryadjaya: His glory and downfall] (Jakarta: Bina Rena Pariwara, 1993).

3. Indonesia, Ministry of Justice, Tambahan Berita Negara [Official gazette supplement], Jakarta.

4. PT Astra International Inc., Annual Report, Jakarta.

5. - Astra, Jakarta.

6. Financial Statements, Jakarta.

7. Information Memorandum Relating to the Public Offer in Indonesia (Jakarta, 1990).

8. "Wawancara: William Soeryadjaya" [Interview: William Soeryadjaya], Eksekutif (Jakarta), No. 7 (January 1980). 